\title{
Phytochemical Screening and Antibacterial Activity Coix lacryma-jobi Oil
}

\author{
Diky Setya Diningrat $\cdot$ Marsal Risfandi $\cdot$ Novita Sari Harahap $\cdot$ Ayu Nirmala Sari $\cdot$ Kusdianti $\cdot$ Henny Kharina Siregar
}

Received: 27 January 2020 / Revised: 17 March 2020 / Accepted: 17 March 2020

(C) Korean Society for Plant Biotechnology

\begin{abstract}
Coix lacryma-jobi (Hanjeli) is known to posses anti-microbial properties. Therefore, phytochemical compounds of C. lacryma-jobi have been studied to produce novel antimicrobial agents as treatments against antibiotic-resistant bacteria.The objective of this study was to determine the phytochemical composition and antibacterial activity of the $C$. lacryma-jobi oil against Escherichia coli, Staphylococcus aureus, and Bacillus subtilis. The phytochemical composition of the oil was determined via gas chromatography mass spectrophotometry (GC-MS). Moreover, agar disk and agar well diffusion were employed to screen the antibacterial activity of the oil. An agar well diffusion test was implemented to determinate MIC's (minimum inhibitory concentrations). Dodecanoic acid, tetradecanoic acid, 2,3-dihydroxypropylester, 1,3-dioctanoin, N-methoxy-N-methyl-3,4-dihydro-2H-thiopyran6-carboxamide, propanamide, 5-Amino-1-(quinolin-8-yl)-1,2,3triazole-4-carboxamide, and pyridine were identified in the $C$. lacryma-jobi oil. The MIC value of the oil was $0.031 \mathrm{~g} / \mathrm{L}$ and the $\mathrm{MBC}$ of the oil was $0.125 \mathrm{~g} / \mathrm{L}$ effective in all test bacteria. Dodecanoic acid displayed inhibitory activity against gram-positive and gram-negative bacteria. Therefore, our research demonstrated C. lacryma-jobi (Hanjeli) oil exhibited antibacterial activity against E. coli, S. aureus, and B. subtilis.
\end{abstract}

D. S. Diningrat $(\bowtie) \cdot H$. K. Siregar

Department Biology, Mathematics and Natural Sciences Faculty, Universitas Negeri Medan, Indonesia

e-mail: dikysd@unimed.ac.id

M. Risfandi $\cdot$ N. S. Harahap

Department Sport Sciences, Faculty Sport Sciences, Universitas Negeri Medan, Indonesia

A. N. Sari

Department Biology, Faculty of Science and Technology,

Universitas Islam Negeri Ar Raniry, Banda Aceh, Indonesia

Kusdianti

Department Biology, Education of Mathematics and Natural Sciences Faculty, Universitas Pendidikan Indonesia, Bandung, Indonesia
These research suggest that $C$. lacryma-jobi root oil could be used for medicinal purposes; however clinical and in vivo tests must be performed to evaluate its potential as an antibacterial agent.

Keywords Phytochemical, antibacterial, essential oil, GCMS, MIC (Minimum Inhibitory Concentrations)

\section{Introduction}

Some species of plants are invaluable resources useful in routine life as an alternative food, food additives, herbs, aroma, color or used directly in pharmaceuticals (Azwanida 2015; Duke 2017). These plant species have content phytochemical properties that have the potential to prevent or treat diseases caused by bacteria (Azwanida 2015; Elisha et al. 2017). The uses of plant extracts and oils in dealing of human diseases have long been firmed (Daniel et al. 2015; Mandal and Mandal 2015). Almost plant extracts have been proven to have antimicrobial property agents that are active against microorganisms in in vitro conditions (Balouiri et al. 2016; Calo et al. 2015; Restuati et al. 2016).

Medicinal plant species used in traditional medicine are effective in dealing with diseases caused by bacteria or oxidant stress (Baydoun et al. 2015; Singh et al. 2017; Restuati and Diningrat 2018). The phenolic phytocomponents from plants play an important role as antimicrobial agents (Diningrat et al 2018; Smeriglio et al. 2017). These antimicrobial agents work by destroying microorganisms through decaying the protein components of the cell wall, disrupting the work of enzymes and also DNA and RNA replication (Bakal et al. 2017).

Essential oils produced from plants are used in industry as food seasonings, pharmaceuticals and medicines (Silou et al. 2017). These oils are designed as a new source of antimicrobial drugs, especially against antibiotic-resistant 
bacteria (Baydoun et al. 2015; Silou et al. 2017). The effectiveness of essential oils as antibacterial has been divided into adequate, moderate or poor quality (Knezevic et al. 2016). These essential oils are also produced by plants as a armament product against several natural enemies. In addition, these essential oils are used to continue their natural growth and development. Even essential oils can contain a number of secondary metabolites or phytochemical compounds in response to some external stress (Knezevic et al. 2016; Silou et al. 2017).

Coix lacryma-jobi is a family of poaceae in the form of panicoid grass, also called Adlay or in some parts of Indonesia called Hanjeli. This annual plant in Indonesia grows wild and is cultivated in some areas which are used as popular nutritional supplements in Chinese traditional medicine. Traditionally, Hanjeli has been used to treat bumps on the skin, bumpy skin, neuralgia, and rheumatism. Modern research shows that Hanjeli seeds have shown bio-activity as antiinflammatory, anti-mutagenic, anti-cancer, anti-allergic, antiobesity, anti-microbial, and anti-oxidant properties (Bon et al. 2017). There is no information yet on essential oils from C. lacryma-jobi root having antimicrobial activity. The importance of this study aims to evaluate the in vitro antibacterial activity of $C$. lacryma-jobi root oil in several bacteria E. coli, S. aureus, and B. subtilis.

\section{Materials and Methods}

Plant sample collection and oil extraction

Hanjeli collected from Pamah Village Area, Semelir District, Langkat District North Sumatra 20773, Indonesia. This research project was conducted from February 2019 to June 2019. Sample of hanjeli roots are washed from impurities and other contaminants.

Distillation of C. lacryma-jobi essential oil was carried out with Steam Distillation: This distillation method draws aromatic molecules from plant roots using heat steam. The power of hot steam could open a storage area where oil was stored in plant material. The essential oil molecules are released from the root of the material C. lacryma-jobi and then evaporate into steam. Steam temperature needs to be controlled so that it can force the roots of C. lacrymajobi to release oil, but excessive heat to burn the roots of C. lacryma-jobi and damage the oil. The resulting essential oil is passed through a cooling system to condense vapors. Dew is a liquid consisting of essential oils and water that must be separated. The vapors produced in this system come from pressures greater than the atmosphere so that they boil above 100 degrees Celsius which facilitates the removal of oil from plant material at a faster rate, and this condition prevents damage to the oil (Duke 2017; Mandal and Mandal 2015).

\section{Phytochemical Screening}

To identify tannins, terpenoids, flavonoids, alkaloids, phenols, phytosterols and saponins in C. lacryma-jobi root oil used standard phytochemical analysis methods according to the Balouiri et al. (2016) and Mandal and Mandal (2015).

Gas chromatography mass spectrometry (GC-MS)

To analyze the phytochemical compounds of C. lacryma-jobi oil GC-MS was used. DB-5 column silica diffusion film was used as thick as $0.25 \mu \mathrm{m}$. The oven temperature setting is at $500^{\circ} \mathrm{C}$ for 5 minutes. Programming the temperature from $50-2800^{\circ} \mathrm{C}$ for 40 minutes. The helium flow rate is set in such a way that is maintained at a speed of $2 \mathrm{ml} /$ min, with a split ratio of $1: 3.1 \mu \mathrm{l}$ of sample is injected with an ionization voltage which is run by the EI technique at 70ev for MS analysis. The volatile essential oil constituents of the MS analyst were identified by matching databases on the engine. The retention index used is the Spectra standard which is matched with the fragmentation patterns that exist in the Mass Spectra29 database. The NIST standard reference database (AMDIA version 2.70) is used to interpret mass spectral data generated from machine readings (Diningrat et al. 2018; Hussein et al. 2016)

\section{Microorganism sources}

The antibacterial activity of C. lacryma-jobi oil was assessed against three bacteria species: E. coli (ATCC No. 25922), S. aureus (ATCC No. 25923) and B. subtilis (ATCC No. 21332), maintained in Laboratory of Department Biology Universitas Negeri Medan, Indonesia at $-20^{\circ} \mathrm{C}$. Each bacterial strain used in this study was activated in the Nutrient broth (NB) medium at $37^{\circ} \mathrm{C}$ for 18 hours. $60 \mu \mathrm{l}$ of bacteria cultured in NB was subcultured to Nutrient agar (NA) and then incubated at $37^{\circ} \mathrm{C}$ for 24 hours. The concentration of bacterial suspension used for the study was then adjusted to obtain a final concentration of around $108 \mathrm{cfu} / \mathrm{ml}$ using NB dilution.

Culture media

Nutrient Broth (NB) and Nutrient Agar (NA) used in this 
study are microbiological growth media commonly used for testing antibiotic sensitivity regulated according to company instructions (Sigma Inc.). The medium is autoclaved and poured as much as $20 \mathrm{ml}$ per plate in a $12 \mathrm{~cm}$ Petri dish. The NB to be used is incubated overnight to ensure medium sterility before use.

Evaluation of antimicrobial activities

To evaluate the antibacterial properties of C. lacryma-jobi oil the standard protocol of the disc agar and well diffusion agar method were used. $1 \mathrm{~g} / \mathrm{L}$ of $C$. lacryma-jobi essential oil resulting from steam distillation is prepared in six serial dilutions (v/v). Each of the $60 \mu$ dilution results are poured in each disk in sequence. As a positive control this study used Kanamycin, while DMSO was used as a negative control. After 24 hours incubation, the diameter of the zone of inhibition against bacterial growth around the disk and well was measured. Using this protocol can determine two values for antibacterial activity, Minimum inhibitory concentration (MIC) and Minimum bactericidal concentration (MBC). For determining the MIC and $\mathrm{MBC}$ values, a microbroth dilution method is also applied. Determination of $\mathrm{MBC}$ can be determined by pouring $60 \mu \mathrm{MIC}$ tubes and six dilutions before filling the agar plate, after the incubation period. The lowest concentration that makes no microbial growth is determined as MBC (Balouiri et al. 2016; Restuati et al. 2016; Restuati and Diningrat 2018).

Statistical Analysis

The notation for antibacterial activity is expressed in terms of the mean value \pm standard error. The resulting data were analyzed by One-way variance analysis (ANOVA) using SPSS 22 software. Data with P value lower than $0.05(\mathrm{p}<$ 0.05 ) were considered to be significantly different (Balouiri et al. 2016; Restuati et al. 2016; Restuati and Diningrat 2018).

\section{Results and Discussion}

\section{Chemical composition}

The investigation of phytochemical screening was The oil of $C$. lacryma-jobi root. The result revealed that the $C$. lacryma-jobi root oil recorded the presence of alkaloid, flavonoid, tannins, Reducing compounds, Flavonoid Anthracenoid, steroids, and Carotenoïds (Table 1).

Table 2 and Fig. 1 show the results of GC-MS analysis on the Coix lacryma-jobi root essential oil. The analysis showed the presence of anti-microbial compounds. Data shown from the results of GC-MS analysis are active fundamental data in the form of Retention Time (RT),

Table 1 Preliminary phytochemical screening of Coix lacryma-jobi root oil

\begin{tabular}{lc}
\hline Chemical groups & Root essential oil \\
\hline Tannins & + \\
Alkaloid salts & + \\
Reducing compounds & + \\
Flavonoid & + \\
Anthracenoid & + \\
steroids & + \\
Carotenoïds & +
\end{tabular}

Table 2 GC-MS analysis of phytocompounds identified in Coix lacryma-jobi root oil

\begin{tabular}{|c|c|c|c|c|}
\hline PEAK & R.T & AREA \% & COMPOUND NAME & Activity \\
\hline 1 & 7.541 & 0.30 & Dodecanoic acid & $\begin{array}{l}\text { Displaying inhibitory activity against gram-positive } \\
\text { and/or gram-negative organisms }\end{array}$ \\
\hline 2 & 9.670 & 0.16 & Tetradecanoic acid & Antitumor activity \\
\hline 3 & 11.046 & 0.04 & 2,3-dihydroxypropyl ester & Pheromone system \\
\hline 4 & 12.542 & 0.04 & 1,3-Dioctanoin & Antiobesity \\
\hline 5 & 13.585 & 0.19 & $\begin{array}{l}\text { N-Methoxy-N-methyl-3,4-dihydro- } \\
\text { 2H-thiopyran-6-carboxamide }\end{array}$ & Antioxidant and neuroprotective \\
\hline 6 & 14.594 & 1.13 & Propanamide & $\begin{array}{l}\text { React in many different organic processes to form } \\
\text { other useful compounds for synthesis. }\end{array}$ \\
\hline 7 & 15.808 & 0.79 & $\begin{array}{l}\text { 5-Amino-1-(quinolin-8-yl)-1,2,3-tri } \\
\text { azole-4-carboxamide }\end{array}$ & $\begin{array}{l}\text { Antiviral, antibacterial, antifungal, antituberculosis, } \\
\text { anticonvulsant, antidepressant, anti-inflammatory, } \\
\text { anticancer }\end{array}$ \\
\hline 8 & 17.500 & 1.50 & Pyridine & $\begin{array}{l}\text { Vitamins, food flavorings, paints, dyes, rubber } \\
\text { products, adhesives, insecticides, and herbicides }\end{array}$ \\
\hline
\end{tabular}




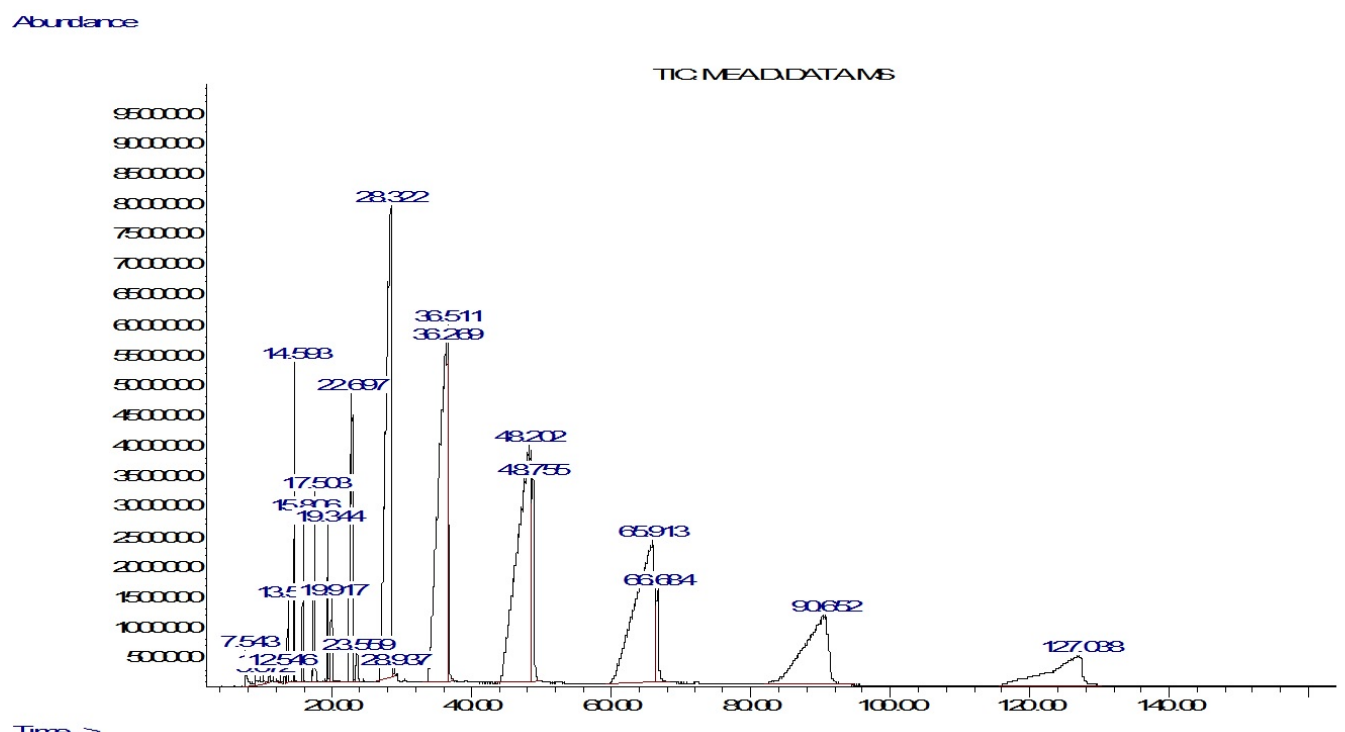

Fig. 1 GC-MS chromatogram for Coix lacryma-jobi root oil

Table 3 Diameters of growth inhibition zones in agar disk diffusion test in different dilutions of Coix lacryma-jobi root oil

\begin{tabular}{lccc}
\hline Dilution $(\mathrm{g} / \mathrm{L})$ & \multicolumn{2}{c}{ Inhibition zone $(\mathrm{mm})$ in disk diffusion } \\
Microorganism & E. coli & S. aureus & Bubtilis \\
\hline Positive control & 22 & 26 & 22 \\
0.125 & 21 & 29 & 24 \\
0.062 & 15 & 17 & 15 \\
0.031 & 9 & 10 & 9 \\
0.015 & 4 & 4 & 3 \\
0.007 & 0 & 0 & 0 \\
0.003 & 0 & 0 & 0 \\
Negative control & 0 & 0 & 0 \\
\hline
\end{tabular}

Molecular Formula (MF), Molecular Weight (MW), and Concentration (peak area\%). The oil of C. lacryma-jobi roots were subjected to GC-MS analysis. Where the data for means the oil of Coix lacryma-jobi roots, some of the important compounds detected in the ethanol fraction include which Dodecanoic acid, Tetradecanoic acid, 2,3-dihydroxypropylester, 1,3-Dioctanoin, N-Methoxy-N-methyl-3,4-dihydro2H-thiopyran-6-carboxamide, Propanamide, 5-Amino-1-(quinolin8-yl)- 1,2,3-triazole-4-carboxamide, Pyridine. Based on Pubchem software analysis results on GC-MS results, it is obtained that the bioactivity of these compounds as Antitumor, Antiobesity, Antioxidant, Neuroprotective, Antiviral, Antibacterial, Anti-fungal, Antituberculosis, Anticonvulsant, Antidepressant, Anti-inflammatory, Antioxidant, Neuroprotective, Antiviral, Antibacterial, Anti-fungal, Antituberculosis, Anticonvulsant, Antidepressant, Anti-inflammatory, Antioxidant, Neuroprotective, Antiviral, Antibacterial, Anti-fungal, Antituberculosis, Anticonvulsant, Antidepressant, Anti-inflammatory, Anti-oxi- dant, Anti-cancer, Vitamin, food seasoning, adhesive, insecticides, and herbicides.

Agar disk diffusion test

The results of testing the antibacterial activity of essential oils showed that E. coli, S. aureus and B. subtilis were sensitive to the un-diluted $C$. lacryma-jobi root oil. The results inhibition zones based on different dilutions are listed in Table 3. The test results also showed that the DMSO treatment did not have inhibitory zones.

Agar well diffusion test

Table 4 shows that the widest of the diameter inhibition zone in $S$. aureus $(29 \mathrm{~mm})$ growth was seen at a concentration of $0.125 \mathrm{~g} / \mathrm{L}$ of Coix lacryma-jobi root oil from steam distillation. At a concentration of $0.007 \mathrm{~g} / \mathrm{L}$ there was 
Table 4 Diameters of growth inhibition zones in agar well diffusion test in different dilutions of Coix lacryma-jobi root oil

\begin{tabular}{lccc}
\hline Dilution $(\mathrm{g} / \mathrm{ml})$ & \multicolumn{3}{c}{ Inhibition zone $(\mathrm{mm})$ in well diffusion } \\
Microorganism & E. coli & S. aureus & B. subtilis \\
\hline Positive control & 22 & 25 & 23 \\
0.125 & 20 & 29 & 21 \\
0.062 & 14 & 14 & 14 \\
0.031 & 8 & 9 & 8 \\
0.015 & 0 & 8 & 0 \\
0.007 & 0 & 0 & 0 \\
0.003 & 0 & 0 & 0 \\
Negative control & 0 & 0 & 0 \\
\hline
\end{tabular}

Table $5 \mathrm{MIC}$ and $\mathrm{MBC}$ of the oil of Coix lacryma-jobi roots

\begin{tabular}{lccc}
\hline Microorganism & E. coli & S. aureus & B. subtilis \\
\hline MIC & 0.031 & 0.031 & 0.031 \\
MBC & 0.125 & 0.125 & 0.125 \\
\hline
\end{tabular}

no inhibition of bacterial growth.

MIC and MBC ascertaining

The lowest MIC value that can be read from observations is at a concentration of $0.031 \mathrm{~g} / \mathrm{ml}$ for E. coli / S. aureus B. subtilis. While the MBC value of the Coix lacryma-jobi root essential oil was $0.125 \mathrm{~g} / \mathrm{ml}$ for E. coli, S. aureus and B. subtilis (Table 5).

Table 5 shows, the oils of $C$. lacryma-jobi roots have prevented the growth of E. coli, S. aureus and B. subtilis. The result also showed, by increasing the concentrations of the oil of Coix lacryma-jobi roots, the inhibition zone increased. The most sensitivity was observed in $S$. aureus.

Table 5 shows that the C. lacryma-jobi root essential oil has prevented the growth of E. coli, S. aureus and B. subtilis. This result also shows that the more the concentration of Coix lacryma-jobi root essential oil increases, the inhibition zone increases. The best sensitivity of the C. lacryma-jobi essential oil is most sensitive to $S$. aureus. The results of statistical analysis on the results of this study indicate that the sensitivity of $C$. lacryma-jobi root essential oil to all bacteria tested, there is a significant difference $(\mathrm{p} \leq 0.005)$.

\section{Discussion}

Coix lacryma-jobi, is an annual flowering plant with white flower is native to Asia include Indonesia. Grains from hanjeli plants are commonly used to cook traditional dishes, such as porridge (Bon et al. 2017). Coix lacryma-jobi has also been used by thousands of people to improve their natural healing abilities (Hussein et al. 2016). Regarding the essential oil distillation method used aims to prevent damage at high temperatures and to reduce the level of damage to effective herbal compounds contained in the oil.

Plant oils have been used in pharmaceuticals, alternative medicine and natural therapies for many thousands of years. Phytochemical compounds contained in essential oils such as tannins, flavonoids and some aromatic compounds or secondary metabolites function as armament in the face of predation either by organisms or many microorganisms. These substances function molecularly as plant defenses against predation by microorganisms, insects, and herbivores. Furthermore, these compounds include plant odors (terpenoids), pigmentation (tannins and quinine), and taste (capsacin) (Knezevic et al. 2016; Silou et al. 2017). The GC-MS analysis results from compounds identified from the essential oil of C. laxryma-jobi root have bioactivity as antimicrobial, antiinflammatory, neuroprotective, and strong antioxidant activity. This is in line with the study of the structure and kinetics of $\mathrm{n}$-hexedeconic acid (palmitic acid) which states that this acid is an inhibitor of phospholipase compounds and acts as an antimicrobial (Hussein et al. 2016; Knezevic et al. 2016).

Therefore initial screening tests were useful in detecting bioactive principle compounds which can further lead to research on drug discovery and development. Coix lacrymajobi essential oil has potential as a new antimicrobial source against bacterial pathogens. In vitro studies in this research indicate that $C$. lacryma-jobi essential oil has an effective 
ability to inhibit pathogens bacterial growth. Earlier reports stated that the antimicrobial activity of many essential oils that had been reviewed was classified as average or medium (Balouiri et al. 2016). However, Coix essential oil is classified in the high classification.

All of these phytocompounds contained in oil had antibacterial effects. The results showed that the C. lacryma-jobi root essential oil with a concentration of about $0.031 \mathrm{~g} / \mathrm{L}$ had inhibited the growth of E. coli, S. aureus and B. subtilis. Thus, this study shows that $C$. lacryma-jobi essential oil is medically antibacterial in gram-negative and gram-positive pathogenic bacteria. A number of authors have mentioned the antimicrobial activity of $C$. lacryma-jobi extract but not oil. The essential oil of $C$. lacryma-jobi roots showed antibacterial activity against $E$. coli, B. cereus and $S$. aureus, our results are in agreement with others who showed that C. lacryma-jobi roots oil produce antimicrobial activity against a broad range of microbes.

\section{Conclusion}

Based on the results of this study it can be concluded that the essential oil of C. lacryma-jobi root has antibacterial activity with inhibition classified as good. Significant statements from this research are that: Essential oil of $C$. lacryma-jobi root can be used as an antibacterial supplement that potential for the development of new therapeutic agents. Additional in vivo and clinical tests are important to justify and further evaluate the potential of C. lacryma-jobi root essential oil as an antibacterial agent.

\section{Conflict of interest statement}

We are all authors of this study stated that we have no conflict of interest in the results of this study.

\section{Acknowledgments}

We, the authors wish to thank Biology Department FMIPA Universitas Negeri Medan, LPPM Universitas Negeri Medan, DRPM Kemenristekdikti Republic of Indonesia (Grant No. 36/UN33.8/PL.DRPM/2019).

\section{References}

Azwanida NN (2015) A review on the extraction methods use in medicinal plants, principle, strength and limitation. Med Aromat Plants 4(196):2167-0412. DOI: 10.4172/2167-0412. 1000196

Bakal SN, Bereswill S, Heimesaat MM (2017) Finding novel antibiotic substances from medicinal plants-antimicrobial properties of Nigella sativa directed against multidrug resistant bacteria. European Journal of Microbiology and Immunology 7(1):92-98. https://doi.org/10.1556/1886.2017.00001

Balouiri M, Sadiki M, Ibnsouda SK (2016) Methods for in vitro evaluating antimicrobial activity: A review. Journal of pharmaceutical analysis 6(2):71-79. https://doi.org/10.1016/ j.jpha.2015.11.005

Baydoun S, Chalak L, Dalleh H, Arnold N (2015) Ethnopharmacological survey of medicinal plants used in traditional medicine by the communities of Mount Hermon, Lebanon. Journal of ethnopharmacology 173:139-156.

Bon SG, Enicola EE, Padasas GY, Galvez HF (2017) Diversity conservation of adlay germplasm in the Philippines. Philippine Journal of Crop Science (Philippines). http://agris.fao.org/ agris-search/search.do?recordID $=$ PH2018000208

Calo JR, Crandall PG, O'Bryan CA, Ricke SC (2015) Essential oils as antimicrobials in food systems $-\mathrm{A}$ review. Food Control 54:111-119. https://doi.org/10.1016/j.foodcont.2014.12.040

Daniel CK, Lennox CL, Vries FA (2015) In vivo application of garlic extracts in combination with clove oil to prevent postharvest decay caused by Botrytis cinerea, Penicillium expansum and Neofabraea alba on apples. Postharvest biology and technology 99:88-92. https://doi.org/10.1016/ j.postharvbio.2014.08.006

Diningrat DS, Restuati M, Kusdianti K, Sari AN, Marwani E (2018) Analisis Ekstrak Etanol Tangkai Daun Buasbuas (Premna pubescens) Menggunakan Gas Chromatography Mass Spectrophotometer(GCMS). Elkawnie 4(1):1-12. https://jurnal. ar-raniry.ac.id/index.php/elkawnie/article/view/3075

Duke JA (2017) Handbook of Phytochemical Constituent Grass, Herbs and Other Economic Plants: Herbal Reference Library. Routledge. https://doi.org/10.1201/9780203752623

Elisha IL, Botha FS, McGaw LJ, Eloff JN (2017) The antibacterial activity of extracts of nine plant species with good activity against Escherichia coli against five other bacteria and cytotoxicity of extracts. BMC complementary and alternative medicine 17(1):133. https://bmccomplementalternmed.bio medcentral. com/articles/10.1186/s12906-017-1645-z

Hussein AO, Mohammed GJ, Hadi MY, Hameed IH (2016) Phytochemical screening of methanolic dried galls extract of Quercus infectoria using gas chromatography-mass spectrometry (GC-MS) and Fourier transform-infrared (FT-IR). Journal of Pharmacognosy and Phytotherapy 8(3):49-59. https://pdfs. semanticscholar.org/4165/23e464d25f046ae2581721989bff e5b7219b.pdf

Knezevic P, Aleksic V, Simin N, Svircev E, Petrovic A, Mimica-Dukic N (2016) Antimicrobial activity of Eucalyptus camaldulensis essential oils and their interactions with conventional antimicrobial agents against multi-drug resistant Acinetobacter baumannii. Journal of ethnopharmacology, 
178:125-136. https://doi.org/10.1016/j.jep.2015.12.008

Mandal S, Mandal M (2015) Coriander (Coriandrum sativum L.) essential oil: Chemistry and biological activity. Asian Pacific Journal of Tropical Biomedicine 5(6):421-428 https://doi.org/ 10.1016/j.apjtb.2015.04.001

Restuati M, Hidayat U, Pulungan ASS, Pratiwi N, Diningrat DS (2016) Antibacterial Activity of Buasbuas (Premna pubescens Blume) Leaf Extracts against Bacillus cereus and Escherichia coli. Journal of Plant Sciences 11(4):81-85. https://scialert.net/ fulltextmobile/?doi=jps.2016.81.85

Restuati M, Diningrat DS (2018) Antimicrobial profile of premna pubescens. Blume and centella asiatica extracts against bacteria and fungi pathogens. International Journal of Pharmacology 14(02):272-275. https://scialert.net/abstract/?doi=ijp.2018.271.275

Silou T, Bikanga R, Nsikabaka S, Nombault J, Mavoungou C, Figuérédo G, Chalchat JC (2017) Aromatic plants from the
Plateau des Cataractes (Congo Basin). Chemotype characterization of essential oil of Cymbopogon nardus (L.) Rendle acclimatized in Congo-Brazzaville. Biotechnologie, Agronomie, Société et Environnement 21(2):105-116. https://www.cabdirect. org/cabdirect/abstract/20173238634

Singh A, Nautiyal MC, Kunwar RM, Bussmann RW (2017) Ethnomedicinal plants used by local inhabitants of Jakholi block, Rudraprayag district, western Himalaya, India. Journal of ethnobiology and ethnomedicine 13(1):49. https://doi.org/ 10.1016/j.jep.2015.06.052

Smeriglio A, Denaro M, Barreca D, Calderaro A, Bisignano C, Ginestra G, Trombetta D (2017) In vitro evaluation of the antioxidant, cytoprotective, and antimicrobial properties of essential oil from Pistacia vera L. Variety Bronte Hull. International journal of molecular sciences 18(6):1212. https://doi.org/10.3390/ijms18061212 